\title{
Til gymnastikkens pris
}

Tidsskriftets anmeldelser har alltid vært populære. I nr. 17/1932 skriver Carl Schiøtz at det har «vært altfor slapt med interessen for gymnastikken og forståelsen av den som et virksomt ledd i hygienen. Gymnastikken har nemlig sin ganske bestemte misjon og kan ikke erstattes av idrett». Derfor anbefaler han sterkt boken han omtaler og oppmuntrer leserne til å prøve øvelsene selv. Han avslutter med en advarsel: «Der følger ofte psykisk insuffisiens med, om man ikke holder sig myk» (Tidsskr Nor Lægeforen 1932; 52: 1060-3).

\section{Bokanmeldelser.}

\section{Preventiv og konstruktiv hygiene.}

En anmeldelse av Arne Faber: «Hjemmegymnastikk.

Sygegymnastikk.» 112 sider. 86 ill. Kjøbenhavn 1932. Ved Carl Schiøtz.

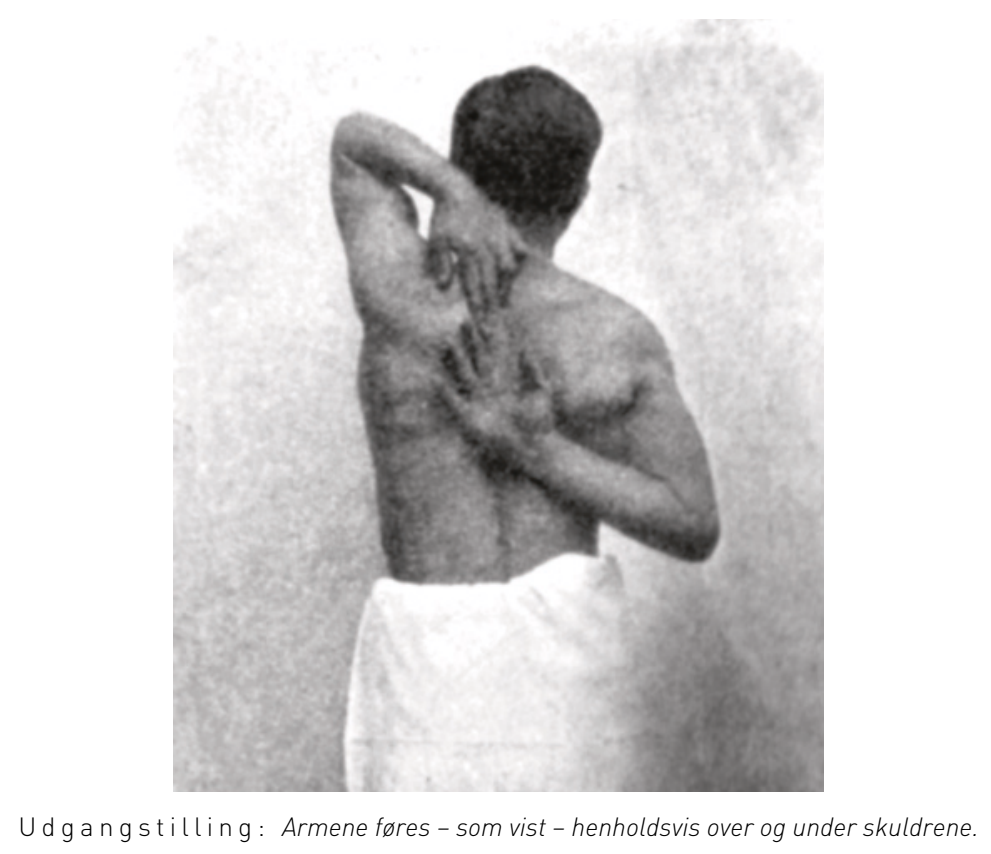

Av forordet: «Mange mennesker, der ikke er helt stærke af natur eller som er reconvalecenter efter en sygdom eller endelig har en eller anden kronisk lidelse - trenger ligesaavel som de helt raske til en daglig motion; disse mennesker bliver let svimle, let trætte og let modløse - og ængstes derfor med rette for de mere voldsomme gymnastikformer.

Denne bog er derfor tænkt som hjælp for alle disse mennesker - et forsøg paa at lære dem at træne deres muskler og hjærte til - uden kortaandethed-at kunne udføre en række gymnastike $\varnothing v e l s e r$, hvis krav er lidt større end de, der til dagligt stilles; kan man tilfredsstille disse krav, bliver dagens byrder lettere.»

Hver øvelse har sin illustrasjon, som den her gjengitte viser. (Fig. 28).

Fotografi med en kort beskrivelse. Videre notater om hvilke muskelgrupper som spesielt settes i funksjon; tallene henviser til Ivar B romanns gruppeinndeling for muskelfunksjoner, hvorav man bak i boken finner en oversikt. Endelig står nederst til høire hensikten med øvelsen (for denne figur: «Led-frigørelsesøvelse for de to skulderled».).

For rekonvalesent-hygi enen tør boken særlig anbefales. Rekonvalesenter skal være i passende grad aktive, de må ikke fortsatt betrakte sig som syke med behov for passiv underkastelse under s y k e b e h a n d l in g.

Boken anbefales sykehuslæger, såvel kirurgiske sådanne (øvelser av de enkelte ledd- og muskelgrupper) som medsinske (et mere generelt valg). Ganske særskilt anbefales den læger ved kursteder. Forf. selv er overlæge ved Silkeborg. Den anbefales også praktiserende læger til studium og eventuelt ad usum proprium. Man kan jo først prøve den øvelse som figuren angir, den ser jo enkel ut. Kanskje man føler at man kunde trenge nogen frigjørelse av skulderleddene. Som eksempel. Ledd- og muskelstivhet er av det onde. Der følger ofte psykisk insuffisiens med, om man ikke holder sig myk. 